\title{
Application of response surface methodology to improve the production of antimicrobial biosurfactants by Lactobacillus paracasei subsp. tolerans N2 using sugar cane molasses as substrate
}

Mouafo T. Hippolyte ${ }^{1,2}$, Mbawala Augustin', Tchougang M. Hervé ${ }^{1}$, Ndjouenkeu Robert ${ }^{1}$ and Somashekar Devappa ${ }^{3^{*}}$

\begin{abstract}
Background: Biosurfactants are natural surface-active compounds produced by a variety of microorganisms. The high cost of culture media limits the large-scale production and use of biosurfactants. It is therefore necessary to develop an efficient and cost-effective bioprocess to improve the yield of biosurfactants from microorganisms. In this study, the response surface method was used to optimize the production of biosurfactants by a Lactobacillus strain and the antimicrobial activity of the biosurfactants was assessed.

Results: The biosurfactant-producing strain was identified as Lactobacillus paracasei subsp. tolerans N2 after 165 rRNA gene analysis. Among the different variables studied using a Plackett-Burman statistical design, temperature and peptone and sugar cane molasses concentrations were found to be the main factors that had significant $(p<0.05)$ influence on biosurfactant production. The results of this study showed that molasses concentration at $59.5 \mathrm{~g} / \mathrm{L}$, peptone at $6.20 \mathrm{~g} / \mathrm{L}$ and temperature of $33^{\circ} \mathrm{C}$ were optimal conditions for biosurfactant production, with a maximum yield of $2.70 \mathrm{~g} / \mathrm{L}$. The biosurfactant exhibited surface tension reduction of $37.85 \mathrm{mN} / \mathrm{m}$ and antimicrobial activity expressed as inhibition diameter of $63 \mathrm{~mm}$. Partial characterizations by elemental, biochemical and Fourier transmission infrared spectroscopy analysis of the biosurfactant produced revealed that it was glycolipoprotein in nature. The biosurfactant exhibited bactericidal activity against Pseudomonas aeruginosa PSB2, Pseudomonas putida PSJ1, Salmonella sp. SL2, Escherichia coli MTCC 118, Bacillus sp. BC1 and Staphylococcus aureus STP1 at concentrations ranging from 6.4 to $50 \mathrm{mg} / \mathrm{mL}$.

Conclusion: The yield of biosurfactant was four-fold higher after optimization of media components and culture conditions using response surface methodology. The results of this study suggested that sugar cane molasses can be used as a low-cost substrate to enhance the yield of biosurfactants with antimicrobial activity.
\end{abstract}

Keywords: Lactobacillus paracasei subsp. tolerans N2, Biosurfactants, Molasses, Optimization, Response surface methodology, Antimicrobial activity

\footnotetext{
*Correspondence: somashekar@cftri.res.in; somshek@hotmail.com

${ }^{3}$ Department of Microbiology and Fermentation Technology, CSIR-

Central Food Technological Research Institute, Mysore, Karnataka 570020,

India

Full list of author information is available at the end of the article
} 


\section{Background}

Microbial surfactants or biosurfactants are surface-active amphiphilic compounds produced by several microorganisms (Ghribi and Ellouze-Chaabouni 2011). They occur in nature as a diverse group of molecules comprising glycolipids, lipopeptides, fatty acids, neutral lipids, phospholipids, polymeric and particulate biosurfactants (Xu et al. 2011). Biosurfactants currently attract considerable attention due to their applications in many industrial fields as substitutes for synthetic surfactants. They are known for their biodegradability and low toxicity and their stability to temperature, $\mathrm{pH}$ and ionic strength (Xu et al. 2011; Satpute et al. 2016). Additionally, biosurfactants are more effective, selective, environmentally friendly and stable than synthetic surfactants (Banat et al. 2000).

Bacteria belonging to the genus Lactobacillus were reported to produce biosurfactants with good antimicrobial activity (Sambanthamoorthy et al. 2014; Gudiña et al. 2015; Mouafo et al. 2018). However, despite the advantages and potential application of these biological compounds, they cannot compete with chemically synthesized compounds due to their high production cost and low production yield (Moussa et al. 2014). The production yield depends on the substrates, which represent about $50 \%$ of the final production cost (Makkar et al. 2011). There is therefore a need to develop an efficient and cost-effective bioprocess for the production of biosurfactants. Hence, research has been focused on the development of novel production strategies such as the formulation of the production media using low-cost substrates and development of innovative production approaches (Freitas de Oliveira et al. 2013). Moreover, the principal problem associated with culture medium is to find substrates with the right balance of nutrients which will support optimum bacterial growth and consequently increase the yield of biosurfactant production (Makkar and Cameotra 2002). Microorganism growth, as well as accumulation of by-products of metabolism like biosurfactants, is influenced by many factors including cell physiology, the nature of constituents in the medium such as carbon and nitrogen sources, inorganic salts and growth factors (Li et al. 2002). Similarly, environmental factors and growth conditions such as temperature, $\mathrm{pH}$, agitation speed and oxygen availability also affect the yield and activity of the biosurfactants (Desai and Banat 1997).

The use of statistical models to optimize culture medium components and conditions in present-day biotechnology research is gaining importance due to their applicability and aptness. The conventional method of optimization involves varying one parameter at a time while keeping the others constant. However, this method often does not bring out the effect of interactions between different parameters, as opposed to factorial design (Griffin et al. 1992). One of the most accepted methodologies used for optimizing medium composition is response surface methodology (RSM), which is widely used for optimization of the process parameters. This statistical technique has been successfully used to optimize medium composition for the synthesis of metabolites and biodegradation processes (Najafi et al. 2011; Huang et al. 2013; Salar et al. 2016). The objective of the present work was to optimize biosurfactant production by a lactobacilli strain using sugar cane molasses as a low-cost substrate in batch fermentation by response surface methodology and to evaluate its antimicrobial properties against foodborne pathogens.

\section{Methods \\ Materials}

Sugar cane molasses used in this study was procured from SOSUCAM (Cameroon Sugar Society). The pathogens used for antimicrobial tests (Pseudomonas aeruginosa PSB2, Pseudomonas putida PSJ1, Salmonella sp. SL2, Escherichia coli MTCC 118, Bacillus sp. BC1 and Staphylococcus aureus STP1) were provided by the laboratory of Food Microbiology and Biotechnology of the National School of Agro-Industrial Sciences of the University of Ngaoundere (Cameroon) and the strain E. coli MTCC 118 was provided by the Department of Microbiology and Fermentation Technology of CSIR-Central Food Technological Research Institute, Mysore (India). Culture media from LiofilChem (Italia) were used in this study.

\section{Identification of the biosurfactant-producing strain}

The biosurfactant-producing strain was isolated from fermented cow milk "pendidam" sold in Ngaoundéré (Cameroon) and identified as bacteria belonging to the genus Lactobacillus after biochemical characterization (Mbawala et al. 2013). The microscopic analysis of the culture was done using an LEO scanning electron microscope (LEO 435 VP Scanning Electron Microscope, UK) according to the method of Song et al. (2010). For molecular identification, the strain's genomic DNA was extracted using a NucleoSpin ${ }^{\circledR}$ Microbial DNA kit according to the manufacturer's instructions (http:// www.mn-net.com/tabid/12621/default.aspx). The universal primers 27F (5'-AGAGTTTGATCMTGGCTC AG-3') and 1492R (5'-GGTTACCTTGTTACGACTT-3') were used in polymerase chain reaction (PCR) to amplify the 16S rRNA gene. The PCR products were purified and sequenced at Sakhala Enterprises (Bangalore, India). The sequences were merged with BioEdit (version 7.0.5.3), and BLAST searched by comparison to known sequences 
in the National Center for Biotechnology Information (NCBI) GenBank database. A query sequence similarity higher than $98 \%$ was used for bacterial identification at the taxonomic level (Guo et al. 2010). The sequences of closely related strains were aligned with the MUSCLE program. The neighbour-joining method was used to construct the phylogenetic tree with MEGA 7 (Kumar et al. 2016). The statistical evaluation of the tree was performed with 1500 bootstrap replicates (Saitou and Nei 1987). Lactococcus lactis subsp. lactis CF112 was used as an out-group microorganism.

\section{Biosurfactant production}

For biosurfactant production, the Lactobacillus strain was inoculated in $1 \mathrm{~L}$ of broth containing $(\mathrm{g} / \mathrm{L}): \quad \mathrm{KH}_{2} \mathrm{PO}_{4}-0.4, \quad \mathrm{NaCl}-0.1, \quad \mathrm{MgSO}_{4} 7 \mathrm{H}_{2} \mathrm{O}-0.1$ and $\mathrm{CaCl}_{2}-0.02$, and $1 \mathrm{~mL}$ of trace elements solution $\left(\mathrm{mg} / 100 \mathrm{~mL}: \mathrm{CuSO}_{4} .5 \mathrm{H}_{2} \mathrm{O}-0.5, \mathrm{H}_{3} \mathrm{BO}_{3}-1.0\right.$, $\mathrm{MnSO}_{4} .5 \mathrm{H}_{2} \mathrm{O}-1.0, \mathrm{ZnSO}_{4}-0.7$ and $\left.\mathrm{MoO}_{3}-1.0\right)$. Peptone, yeast extract, sugar cane molasses and $\mathrm{K}_{2} \mathrm{HPO}_{4}$ at different concentrations based on preliminary studies were also added (Table 1). Broth $\mathrm{pH}$ was adjusted to 6.70 before sterilization. At the end of the fermentation, the culture was centrifuged at $7000 \mathrm{rpm}$ and $4{ }^{\circ} \mathrm{C}$ for $20 \mathrm{~min}$ (Biofuge Primo R, Thermo Scientific, USA) to remove bacterial cells. The cell-free supernatant was filtered $(0.22 \mu \mathrm{m}$; Millipore, Germany) and stored for tests.

\section{Experimental design and statistical analysis Identification of significant nutrient components and culture conditions}

The effect of culture conditions such as temperature, incubation time, agitation speed, inoculum, sugar cane molasses, peptone, yeast extract and $\mathrm{K}_{2} \mathrm{HPO}_{4}$ on biosurfactant production was evaluated using a PlackettBurman statistical design. This design is a fraction of a two-level factorial design which allows the investigation of $n-1$ variables with $n$ experiments. It assumes that there are no interactions between the different factors (Kammoun et al. 2008). A total of 15 experiments were conducted with three dummy variables. The three dummy variables were carried out to provide an adequate estimate of the error. All the trials were performed in triplicate. The domain of variation of the eight factors (cultural conditions) defined by preliminary tests and the experimental matrix of the different trials are presented in Table 1. The Plackett-Burman experimental design used was based on the first-order model equation:

$$
Y=b_{0}+\sum b_{i} x_{i}
$$

where $Y$ is the response (surface tension, antimicrobial activity, and yield of biosurfactants), $b_{0}$ is the model intercept and $b_{i}$ is the variables estimated. The main effect of factors was calculated as the difference between the average of measurements made at the high-level setting $(+1)$ and the average of measurements observed at the low-level setting $(-1)$ of each factor (Kammoun et al. 2008). The significance of each variable was determined via their $p$-values by the statistical software STATGRA PHICS Centurion XVI version 16.1.18 (StatPoint Technologies, Inc.). The variables with $p$-values lower than 0.05 were considered to have a significant effect on biosurfactant production.

\section{Optimization of culture conditions using a central composite design}

In order to determine the optimal conditions for biosurfactant production, a central composite design was adopted, consisting of a complete $2^{k}$ factorial design ( $k$ being the number of test variables), $2^{*} k$ star points and six replicates at the central point. The axial distance $\alpha$ was chosen to be $\alpha=2^{k / 4}$ to have satisfactory orthogonality and make the design rotatable. Six centre points were chosen to estimate the experimental error of the method, and the experimental design is given in Table 3. Experiments were randomized to minimize the effect of unexplained variability on the observed responses due to extraneous factors. Each factor in the design was assessed at five levels $(-\alpha,-1,0,+1$ and $+\alpha)$. For each experiment, the responses (yield of biosurfactant, antimicrobial activity and surface tension) were evaluated in triplicate, and the average was used to calculate the coefficient. These coefficients were related to the coded factors by a second-order polynomial model using the equation below:

$$
Y=\beta_{0}+\sum_{i=1}^{k} \beta_{i} X_{i}+\sum_{i=1}^{k} \beta_{i i} X_{i}^{2}+\sum \sum_{i<j}^{k} \beta_{i j} X_{i} X_{j}+\varepsilon
$$

where $Y$ refers to the predicted response, $X_{i}$ and $X_{j}$ to the independent coded variables, $\beta_{0}$ to the offset term, $\beta_{i}$ to the coefficient of the linear terms, $\beta_{i i}$ to the coefficient of the quadratic terms and $\beta_{i j}$ to the coefficient of the interaction terms.

The statistical software STATGRAPHICS Centurion and Minitab 16 (Minitab Inc.) were used to conduct a regression analysis on the experimental data, and the statistical software SigmaPlot 12 version 12.5.0.38 (Systat Software, Inc.) was used to plot the response surface graphs. The statistical significance of the model parameters $(p<0.05)$ was checked by analysis of variance (ANOVA) for each response. The model adequacies were checked by the coefficient of determination $R^{2}$, adjusted$R^{2}\left(\operatorname{adj}-R^{2}\right)$, the absolute average deviation (AAD), the 


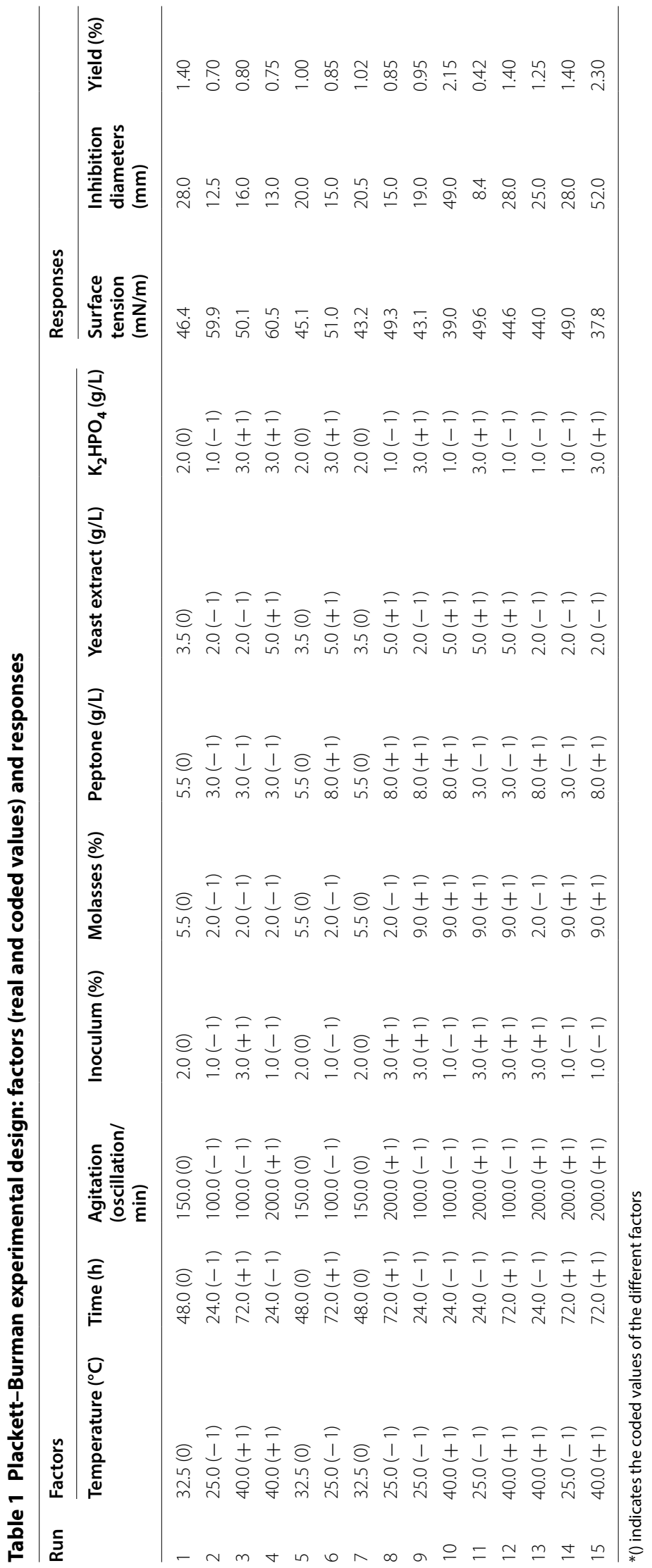


accuracy factor $\left(A_{f}\right)$, the bias factor $\left(B_{f}\right)$ and lack-offit test. The model was considered to be valid where $R^{2} \geq 80 \%, 0<\mathrm{AAD}<0.3,0.75<A_{f}<1.25$ and $0.75<B_{f}<1.25$ (Bas and Boyaci 2007).

$$
\begin{gathered}
A A D=\frac{\left[\sum_{i=1}^{N}\left(\frac{\left|Y_{i, e x p}-Y_{i, c a l}\right|}{Y_{i, \text {exp}}}\right)\right]}{N} \\
B_{f}=10^{B} B=\frac{\sum_{i=1}^{N} \log \left(\frac{Y_{i, c a l}}{Y_{i, \text { exp }}}\right)}{N} \\
A_{f}=10^{A} A=\frac{\sum_{i=1}^{N}\left|\log \left(\frac{Y_{i, \text { cal }}}{Y_{i, \text { exp }}}\right)\right|}{N}
\end{gathered}
$$

\section{Optimization procedure and validation of models}

The polynomial second-order equations which related the independent factors to the responses were computed graphically to determine the workable optimum conditions. The desired goals for each response variable were chosen as maximized while keeping all the factors within range. A multi-response optimization based on desirability method was applied to find the best combination of the factors that would result in maximizing the yield and antimicrobial activity of biosurfactant while minimizing its surface activity. The adequacy of response surface models for predicting the optimum response values was verified by conducting experiments in triplicate under the recommended optimum conditions, and both predicted and experimental values of the responses were compared using a $t$ test.

\section{Surface tension measurement}

The surface tension of supernatants was determined by the ring method of Devesa-Rey et al. (2011). The ring $\left(3 \mathrm{~cm}\right.$ of diameter) of a tensiometer (3B Scientific ${ }^{\circledR}$ product U20030, USA) was placed just below the surface of the supernatant solutions. Subsequently, the force required to move this ring from the liquid phase to the air phase was measured and used for calculating the surface tension. The measurements were carried out in triplicate, and distilled water was used as a control.

\section{Extraction of biosurfactant}

The biosurfactants were extracted from the cell-free supernatant using the solvent method described by Fracchia et al. (2010). The cell-free supernatant was acidified to $\mathrm{pH} 2.0$ with $6 \mathrm{~N} \mathrm{HCl}$, stored overnight at $4{ }^{\circ} \mathrm{C}$ and extracted three times with ethyl acetate/methanol (4:1). The organic fraction was evaporated to dryness under vacuum condition in a rotavapor (Heidolph VV60), and acetone was added to recover the raw biosurfactants. The acetone was evaporated, and the biosurfactants were dissolved in methanol, centrifuged $\left(13,000 \mathrm{~g}, 4{ }^{\circ} \mathrm{C}, 10 \mathrm{~min}\right)$, filtered $(0.22 \mu \mathrm{m})$ and evaporated to dryness under nitrogen. The biosurfactants recovered were stored at room temperature for analysis.

\section{Characterization of biosurfactant Elemental composition}

The biosurfactants was analyzed for their elemental composition (\% C, H, N, O, S) using a Vario EL III (Elementar, Germany) elemental analyzer. Approximately $3 \mathrm{mg}$ of biosurfactant was encapsulated in a tin aluminium capsule and pyrolyzed in a furnace at $1100{ }^{\circ} \mathrm{C}$ with pure oxygen under static condition. The oxidized products were reduced, and the percentages of $\mathrm{C}, \mathrm{H}, \mathrm{N}$ and $\mathrm{S}$ were registered by the integrator connected to the analyzer. The oxygen percentage of samples was calculated from the difference of $\mathrm{C}, \mathrm{H}, \mathrm{N}$ and $\mathrm{S}$, and sulphanilic acid was used as internal standard (Telmo et al. 2010).

\section{Biochemical composition}

The total protein content of biosurfactant was estimated using the Kjeldahl method (AACC 1999), the total sugar content with the phenol-sulfuric method (Dubois et al. $1956)$ and the total lipid content according to the protocol described by Lobna and Ahmed (2013).

\section{Fourier transmission infrared spectroscopy (FTIR)}

The functional groups of the biosurfactant were identified with an FTIR spectrometer (Tensor II, IFS 25, Bruker Germany) using the attenuated total reflectance (ATR) system. $1 \mathrm{mg}$ of biosurfactants was placed on the ATR crystal and scanned at a resolution of $2 \mathrm{~cm}^{-1}$ over the range of $400-4000 \mathrm{~cm}^{-1}$. The ATR spectra obtained were collected with a DTGS detector.

\section{Antimicrobial activity}

The antimicrobial activity of the biosurfactant was tested against Pseudomonas putida PSJ1, a strain isolated from ground beef marketed in Ngaoundéré (Cameroon). From the frozen stock, the strain was sub-cultured twice in trypticase soy broth (TSB, LiofilChem, Italy) at $37{ }^{\circ} \mathrm{C}$ for $24 \mathrm{~h}$. For the antimicrobial test, the agar well diffusion method was used following the protocol described by Topisirovic et al. (2006). Prior to analysis, cell-free supernatants were treated with catalase (catalase $2.0 \mathrm{U} / \mathrm{mg}$ in phosphate buffer $10 \mathrm{mM}, \mathrm{pH}$ 7), proteinase $\mathrm{K}(50 \mathrm{UI} / \mathrm{mL}$ in phosphate buffer $50 \mathrm{mM}, \mathrm{pH} 6.5$ ) and neutralized to pH 7.0 with $0.1 \mathrm{~N} \mathrm{NaOH} .100 \mu \mathrm{L}$ of P. putida PSJ1 suspension $\left(10^{6} \mathrm{CFU} / \mathrm{mL}\right)$ of $18 \mathrm{~h}$ was inoculated into Petri dishes containing $20 \mathrm{~mL}$ of sterile Mueller-Hinton agar (MH, LiofilChem, Italy). The inoculated plates were left 
for $1 \mathrm{~h}$ in the laminar hood to allow the suspension to solidify. Wells of $6 \mathrm{~mm}$ diameter were filled with $25 \mu \mathrm{L}$ of the biosurfactant. The Petri dishes were stored at $4{ }^{\circ} \mathrm{C}$ for $4 \mathrm{~h}$ before incubating at $37^{\circ} \mathrm{C}$ for $24 \mathrm{~h}$. After incubation, the diameter of the inhibition zone was measured. Each test was carried out in triplicate.

Determination of minimum inhibitory concentration (MIC) The antimicrobial activity of biosurfactants against Pseudomonas aeruginosa PSB2, Pseudomonas putida PSJ1, Salmonella sp. SL2, E. coli MTCC 118, Bacillus sp. BC1 and Staphylococcus aureus STP1 was quantified using the method of Gudiña et al. (2011) with slight modifications. The test tubes containing $4 \mathrm{~mL}$ of sterile TSB were inoculated with $0.5 \mathrm{~mL}$ of overnight bacterial culture $\left(10^{8} \mathrm{CFU} /\right.$ $\mathrm{mL}$ ). Biosurfactant at different concentrations (from 0.10 to $100.0 \mathrm{mg} / \mathrm{mL}$ ) was taken in sterile phosphate buffered saline (pH 7.0) and added to the test tubes containing different bacterial pathogens. The final volume in each test tube was adjusted to $5 \mathrm{~mL}$ with TSB. A test tube without bacterial strain and a test tube without biosurfactant were also prepared and used as negative and growth controls, respectively. Tubes were incubated for $24 \mathrm{~h}$ at $37^{\circ} \mathrm{C}$. After incubation, the absorbance at $600 \mathrm{~nm}$ of each tube was measured using a spectrophotometer (UV-1800, Shimadzu, USA). MIC was determined for each strain as the lowest concentration of biosurfactant that completely inhibited measurable growth $\left(A_{600}=0\right)$.

\section{Determination of minimum bactericidal concentration (MBC)}

MBC was established in liquid media and further confirmed in solid media. In liquid media, $100 \mu \mathrm{L}$ of the culture fluid which was used for $\operatorname{MIC}\left(A_{600}=0\right)$ was transferred into a test tube containing $5 \mathrm{~mL}$ of sterile TSB and incubated for $24 \mathrm{~h}$ at $37{ }^{\circ} \mathrm{C}$. Afterwards, the absorbance of each tube at $600 \mathrm{~nm}$ was measured. In solid media, $100 \mu \mathrm{L}$ of the culture fluid which was used for MIC $\left(A_{600}=0\right)$ was plated in specific culture media of each pathogenic strain followed by incubation at $37^{\circ} \mathrm{C}$ for $24 \mathrm{~h}$. The lowest concentration of biosurfactant that did not allow growth both in solid and liquid media was considered to be the MBC.

\section{Scanning electron microscope (SEM) analysis}

The effect of biosurfactant on bacterial cell morphology was assessed according to the protocol described by Sambanthamoorthy et al. (2014) with slight modifications. Briefly, E. coli MTCC 118 was cultured for $18 \mathrm{~h}$ at $37^{\circ} \mathrm{C}$ in $1.5 \mathrm{~mL}$ of Luria-Bertani broth (LB, HiMedia, India). The culture was then centrifuged $\left(10,000 g, 4{ }^{\circ} \mathrm{C}, 5 \mathrm{~min}\right)$. The cells were washed with phosphate buffer $0.1 \mathrm{M}(\mathrm{pH} 7.2)$, resuspended in $1 \mathrm{~mL}$ biosurfactant solution $(1 \times \mathrm{MBC})$ in phosphate buffer $0.1 \mathrm{M}$ and incubated at $37{ }^{\circ} \mathrm{C}$ for $12 \mathrm{~h}$. Non-treated cells were used as the control. After incubation, cells were collected by centrifugation, washed twice with phosphate buffer $0.1 \mathrm{M}$ and fixed at $4{ }^{\circ} \mathrm{C}$ for $24 \mathrm{~h}$ with $1 \mathrm{~mL}$ of glutaraldehyde $3 \%$. Subsequently, cells were washed twice and dehydrated for $10 \mathrm{~min}$ with a series of graded absolute ethanol (30, 50, 70, 80, 90, 95\%). The dehydrated cells were suspended in absolute ethanol and subjected to SEM analysis (LEO 435 VP Scanning Electron Microscope, UK).

\section{Results and discussion \\ Identification of the biosurfactant-producing strain}

The morphological examination of the strain Lactobacillus sp. N2 under SEM analysis showed that it consists of rod-shaped cells with lengths ranging between 0.8 and $2 \mu \mathrm{m}$. They appeared singly or in pairs. Similar morphological properties were reported by Dellaglio and Dicks (1991) regarding the description of lactobacilli strains belonging to the species L. paracasei. After comparing the 16S rRNA sequence of the strain N2 with those deposited in the NCBI GenBank database through nucleotide BLAST analysis, the strain showed 100\% similarity to L. paracasei subsp. tolerans $\mathrm{H}$, a strain isolated by Hamzehlou et al. (2018) (unpublished data, accession number: MG818769). The biosurfactant-producing strain isolated from a traditional fermented milk "pendidam" in Ngaoundéré (Cameroon) was designated L. paracasei subsp. tolerans N2 and deposited in GenBank under accession number MH142620. Strains of L. paracasei species isolated from the Portuguese dairy industry have been reported to produce biosurfactants (Gudiña et al. 2010).

\section{Identification of significant nutrient components and culture conditions}

The different values of responses assessed are presented in Table 1 . The multilinear regression analysis of each response obtained the estimations of the model coefficients and respective equations, as follows:

$$
\begin{aligned}
Y_{1}= & 2.196+0.713 X_{1}+0.230 X_{2}+0.198 X_{3}-0.479 X_{4} \\
& +0.915 X_{5}+0.758 X_{6}-0.017 X_{7}-0.279 X_{8} \\
Y_{2}= & 74.199-0.287 X_{1}-0.049 X_{2}+0.004 X_{3}-1.375 X_{4} \\
& -1.230 X_{5}-1.650 X_{6}+0.561 X_{7}-0.525 X_{8} \\
Y_{3}= & -0.724+0.045 X_{1}+0.004 X_{2}+0.0002 X_{3}-0.256 X_{4} \\
& +0.095 X_{5}+0.116 X_{6}+0.054 X_{7}-0.140 X_{8}
\end{aligned}
$$

where $Y_{1}=$ inhibition diameter against Pseudomonas putida PSJ1, $Y_{2}=$ surface tension, $Y_{3}=$ yield of biosurfactants, $X_{1}=$ temperature, $X_{2}=$ time, $X_{3}=$ agitation speed, $X_{4}=$ inoculum concentration, $X_{5}=$ sugar 
cane molasses concentration, $X_{6}=$ peptone concentration, $X_{7}=$ yeast extract concentration and $X_{8}=\mathrm{K}_{2} \mathrm{HPO}_{4}$ concentration.

The values of $R^{2}$ and adj- $R^{2}$ of each model were higher than $80 \%$ (Table 2). This means that all these models can be used to explain the observed phenomena. It also indicates a good adjustment of these regression models to the experimental data. Moreover, the non-significant values of lack-of-fit obtained for the different models also confirmed this observation. Therefore, sugar cane molasses concentration, peptone concentration and temperature were retained for further optimization using a central composite design.

\section{Optimization of biosurfactant production Model fitting}

The experimental values of each response are presented in Table 3. They show stochastic variations in the responses measured, suggesting the effects of the various culture components and culture conditions on microbial activities. The multilinear regression analysis of each response obtained the estimations of the model coefficients and respective equations as follows:

$$
\begin{aligned}
Y_{1}= & 2.546+0.246 X_{1}+0.157 X_{2}+0.218 X_{3} \\
& +0.094 X_{1} X_{2}-0.395 X_{1} X_{3}-0.070 X_{2} X_{3} \\
& -0.458 X_{1}^{2}-0.864 X_{2}^{2}-0.322 X_{3}^{2} \\
Y_{2}= & 37.402-3.023 X_{1}-1.072 X_{2}-2.834 X_{3} \\
& -0.735 X_{1} X_{2}+5.192 X_{1} X_{3}+0.367 X_{2} X_{3} \\
& +3.790 X_{1}^{2}+7.287 X_{2}^{2}+3.194 X_{3}^{2}
\end{aligned}
$$

$$
\begin{aligned}
Y_{3}= & 60.776+5.879 X_{1}+3.051 X_{2}+3.778 X_{3} \\
& -0.161 X_{1} X_{2}-9.368 X_{1} X_{3}-0.243 X_{2} X_{3} \\
& -7.283 X_{1}^{2}-21.376 X_{2}^{2}-10.777 X_{3}^{2}
\end{aligned}
$$

where $Y_{1}$ represents the yield of biosurfactants, $Y_{2}$ the surface tension, $Y_{3}$ the inhibition diameter, $X_{1}$ the peptone concentration, $X_{2}$ the temperature and $X_{3}$ the molasses concentration.

The values of the different elements used to assess the models' adequacy are given in Table $4 . R^{2}$ and adj- $R^{2}$ were found to be higher than $93 \%$. The results indicate that more than $93 \%$ of variabilities in the respective responses could be explained by these models. These results are in accordance with those of Sayyad et al. (2007) who reported that a model would better explain the variability between the experimental and the model predicted values when the $R^{2}$ value is closer to $100 \%$. The non-significance of the lack-of-fit test (Table 4) also showed the strength of the model for the experimental data. The others elements such as AAD, $A_{f, \text { and }} B_{f}$ obtained in this study were in the range reported by Bas and Boyaci (2007), thus confirming the satisfactory fit

\begin{tabular}{|c|c|c|c|c|c|c|c|c|c|c|c|c|}
\hline \multirow[t]{2}{*}{ Factors } & \multicolumn{4}{|c|}{ Inhibition diameter } & \multicolumn{4}{|c|}{ Surface tension } & \multicolumn{4}{|c|}{ Yield } \\
\hline & DF & Sum of squares & $F$-value & $p$-value & DF & Sum of squares & $F$-value & $p$-value & DF & Sum of squares & $F$-value & $p$-value \\
\hline$X_{1}$ & 1 & 603.501 & 30.050 & $0.031^{*}$ & 1 & 55.900 & 21.580 & $0.043^{*}$ & 1 & 1.387 & 27.630 & $0.034^{*}$ \\
\hline$x_{2}$ & 1 & 61.200 & 3.050 & 0.223 & 1 & 17.040 & 6.580 & 0.124 & 1 & 0.158 & 3.160 & 0.217 \\
\hline$x_{3}$ & 1 & 0.300 & 0.010 & 0.913 & 1 & 0.520 & 0.200 & 0.697 & 1 & 0.001 & 0.020 & 0.891 \\
\hline$X_{4}$ & 1 & 281.301 & 14.010 & 0.064 & 1 & 22.687 & 8.760 & 0.097 & 1 & 0.790 & 15.750 & 0.058 \\
\hline$x_{5}$ & 1 & 643.868 & 32.060 & $0.029^{*}$ & 1 & 222.741 & 86.000 & $0.011^{*}$ & 1 & 1.346 & 26.820 & $0.035^{*}$ \\
\hline$x_{6}$ & 1 & 397.901 & 19.810 & $0.046^{*}$ & 1 & 204.188 & 78.840 & $0.012^{*}$ & 1 & 1.009 & 20.100 & $0.046^{*}$ \\
\hline$x_{7}$ & 1 & 48.400 & 2.410 & 0.260 & 1 & 8.500 & 3.280 & 0.211 & 1 & 0.080 & 1.590 & 0.334 \\
\hline$x_{8}$ & 1 & 96.900 & 4.820 & 0.159 & 1 & 3.307 & 1.280 & 0.375 & 1 & 0.235 & 4.680 & 0.163 \\
\hline Lack of fit & 4 & 52.829 & 0.660 & 0.677 & 4 & 43.422 & 4.190 & 0.201 & 4 & 0.133 & 0.660 & 0.675 \\
\hline Pure error & 2 & 40.166 & & & 2 & 5.180 & & & 2 & 0.100 & & \\
\hline Total (corr.) & 14 & 2226.37 & & & 14 & 583.489 & & & 14 & 5.242 & & \\
\hline$R^{2}$ & & & 95.82 & & & & 91.67 & & & & 95.34 & \\
\hline Adjusted $R^{2}$ & & & 90.25 & & & & 80.56 & & & & 89.60 & \\
\hline
\end{tabular}
of the regression models to the experimental data.

\section{Effect of culture conditions on the production of biosurfactant}

Temperature, molasses concentration and peptone concentration were the main significant factors that greatly affected the growth and production of biosurfactant by lactobacilli. The interactive effects of these

Table 2 ANOVA of the different responses assessed for the Plackett-Burman design

$X_{1}$ : Temperature; $X_{2}$ : time; $X_{3}$ : agitation speed; $X_{4}$ : inoculum concentration; $X_{5}$ : sugar cane molasses concentration; $X_{6}$ : peptone concentration; $X_{7}$ : yeast extract concentration; $X_{8}: \mathrm{K}_{2} \mathrm{HPO}_{4}$ concentration; DF: degrees of freedom; *significant at $p<0.05$ 
Table 3 Matrix of central composite design of independent variables for the production of biosurfactants

\begin{tabular}{|c|c|c|c|c|c|c|}
\hline \multirow[t]{2}{*}{ Runs } & \multicolumn{3}{|l|}{ Factors } & \multicolumn{3}{|l|}{ Responses } \\
\hline & Peptone (g/L) & Temperature $\left({ }^{\circ} \mathrm{C}\right)$ & Molasses $(\%, \mathrm{~m} / \mathrm{v})$ & Yield (g/L) & $\begin{array}{l}\text { Inhibition } \\
\text { diameter (mm) }\end{array}$ & $\begin{array}{l}\text { Surface } \\
\text { tension } \\
(\mathrm{mN} / \mathrm{m})\end{array}$ \\
\hline 1 & $8.00(+1)$ & $40.00(+1)$ & $9.00(+1)$ & 1.00 & 21.50 & 49.91 \\
\hline 2 & $5.50(0)$ & $32.50(0)$ & $5.50(0)$ & 2.62 & 63.70 & 36.71 \\
\hline 3 & $1.68(-a)$ & $32.50(0)$ & $5.50(0)$ & 1.20 & 38.20 & 48.01 \\
\hline 4 & $5.50(0)$ & $32.50(0)$ & $5.50(0)$ & 2.60 & 62.78 & 36.98 \\
\hline 5 & $5.50(0)$ & $44.00(+a)$ & $5.50(0)$ & 0.71 & 19.00 & 52.66 \\
\hline 6 & $5.50(0)$ & $32.50(0)$ & $5.50(0)$ & 2.74 & 63.60 & 36.01 \\
\hline 7 & $3.00(-1)$ & $25.00(-1)$ & $9.00(+1)$ & 1.00 & 22.82 & 49.09 \\
\hline 8 & $5.50(0)$ & $32.50(0)$ & $0.16(-a)$ & 1.20 & 33.07 & 48.72 \\
\hline 9 & $9.31(+a)$ & $32.50(0)$ & $5.50(0)$ & 1.70 & 52.12 & 43.19 \\
\hline 10 & $5.50(0)$ & $32.50(0)$ & $5.50(0)$ & 2.36 & 54.12 & 39.13 \\
\hline 11 & $8.00(+1)$ & $40.00(+1)$ & $2.00(-1)$ & 1.96 & 37.23 & 42.38 \\
\hline 12 & $8.00(+1)$ & $25.00(-1)$ & $9.00(+1)$ & 0.90 & 23.12 & 51.28 \\
\hline 13 & $3.00(-1)$ & $25.00(-1)$ & $2.00(-1)$ & 0.099 & 0.10 & 63.80 \\
\hline 14 & $8.00(+1)$ & $25.00(-1)$ & $2.00(-1)$ & 1.00 & 27.02 & 49.10 \\
\hline 15 & $5.50(0)$ & $32.50(0)$ & $5.50(0)$ & 2.35 & 64.90 & 38.07 \\
\hline 16 & $5.50(0)$ & $23.00(-a)$ & $5.50(0)$ & 0.30 & 5.80 & 54.80 \\
\hline 17 & $5.50(0)$ & $32.50(0)$ & $5.50(0)$ & 2.653 & 53.78 & 38.34 \\
\hline 18 & $3.00(-1)$ & $40.00(+1)$ & $9.00(+1)$ & 1.30 & 32.70 & 46.78 \\
\hline 19 & $5.50(0)$ & $32.50(0)$ & $10.83(+a)$ & 2.33 & 41.01 & 39.71 \\
\hline 20 & $3.00(-1)$ & $40.00(+1)$ & $2.00(-1)$ & 0.10 & 0.10 & 63.90 \\
\hline
\end{tabular}

*() indicates the coded values of the different factors

variables on the system's responses were investigated by plotting three-dimensional curves of the response against any two of the variables. The remaining variable was kept at its central value. Response surface plots were used as they allow an easy interpretation of experimental results and prediction of optimal conditions. Figure $1 \mathrm{a}-\mathrm{c}$ shows that the yield and activities of biosurfactant increase progressively as temperature and molasses concentration increase. The positive and significant effect of the temperature on yield and antibacterial activity with its negative and significant effect on surface tension reduction also show that an increase in temperature stimulates the production of biosurfactant by $L$. paracasei $\mathrm{N} 2$. The maximum yield and biosurfactant activities were observed at temperatures ranging from 33 to $34{ }^{\circ} \mathrm{C}$ and molasses concentrations from 5.49 to $6.35 \%(\mathrm{w} / \mathrm{v})$. This result shows that temperature range $33-34{ }^{\circ} \mathrm{C}$ is required by the strain $L$. paracasei $\mathrm{N} 2$ to efficiently utilize peptone and molasses to produce a maximum yield of biosurfactant with high antimicrobial and surface activities. However, outside this temperature range, a decrease in yield and activities of biosurfactant produced by $L$. paracasei N2 was observed. This inhibition can be observed firstly with the negative and significant $(p<0.05)$ effect of the quadratic term of temperature on yield and antimicrobial activity of biosurfactant and secondly by the positive and significant $(p<0.05)$ effect of temperature on the reduction of surface tension. The inhibition of biosurfactant production at high temperature may be because each microorganism has an optimal temperature for cell growth and the metabolic activities varied accordingly for biosurfactant production. An increase in temperature may have led to the inhibition of cell growth and indirectly the production of biosurfactant. Rodrigues et al. (2006a) showed in their study that among Lactobacillus strains the production of biosurfactants by $L$. pentosus occurred mainly at $31{ }^{\circ} \mathrm{C}$ whereas, for other lactobacilli strains, it occurred at $37^{\circ} \mathrm{C}$.

The response surface plot of Fig. $1 \mathrm{~d}-\mathrm{f}$ shows the effect of peptone concentration and temperature on the yield and activity of biosurfactants produced by $L$. paracase $i$ N2. It can be seen from Fig. 1 that increase in peptone concentration up to $6 \mathrm{~g} / \mathrm{L}$ and temperature from 30 to $35{ }^{\circ} \mathrm{C}$ stimulates the production of biosurfactant. The linear coefficients of peptone concentration on the yield, antimicrobial activity and surface tension reduction of biosurfactants also show the positive effect of increased 


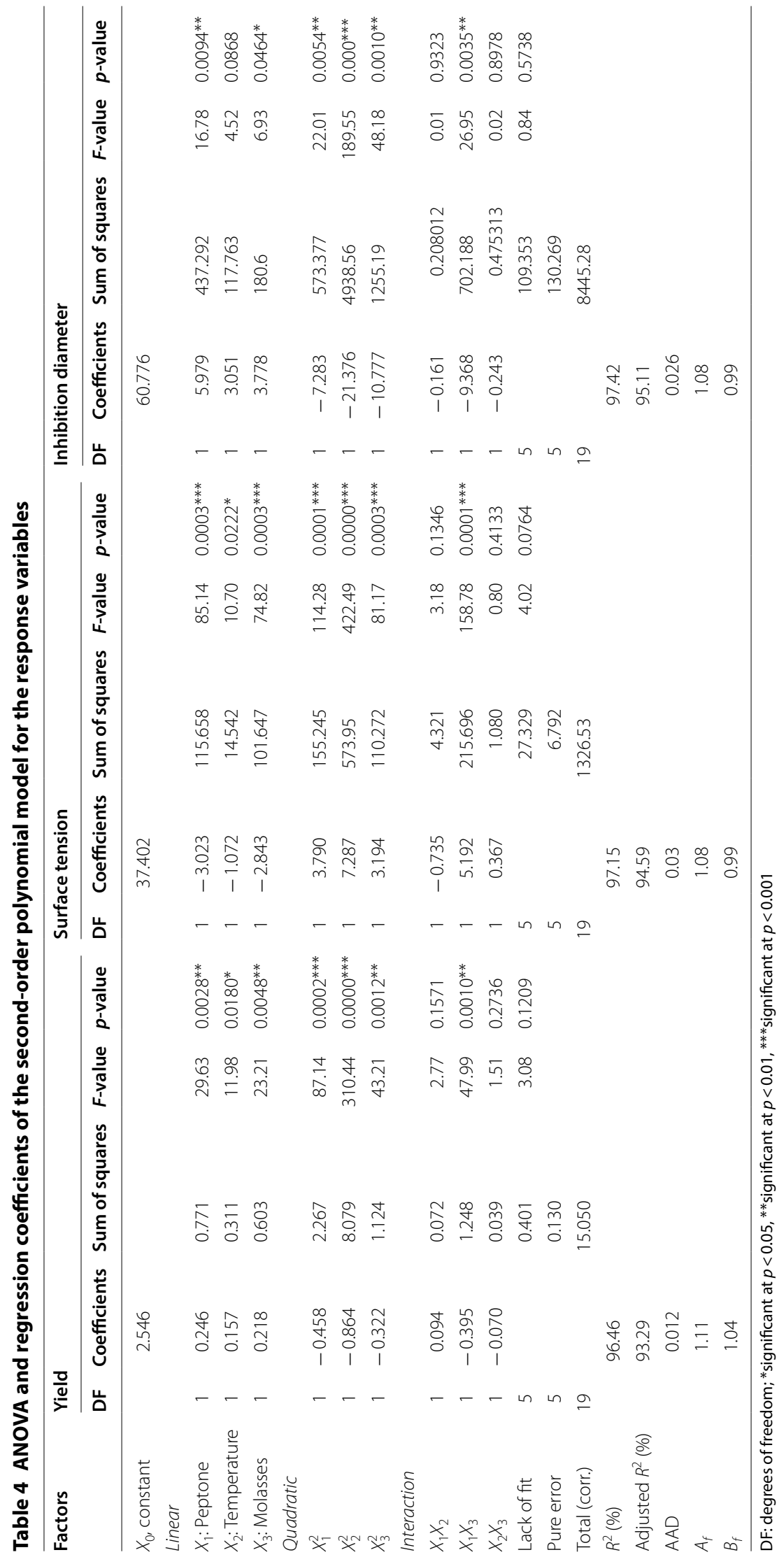



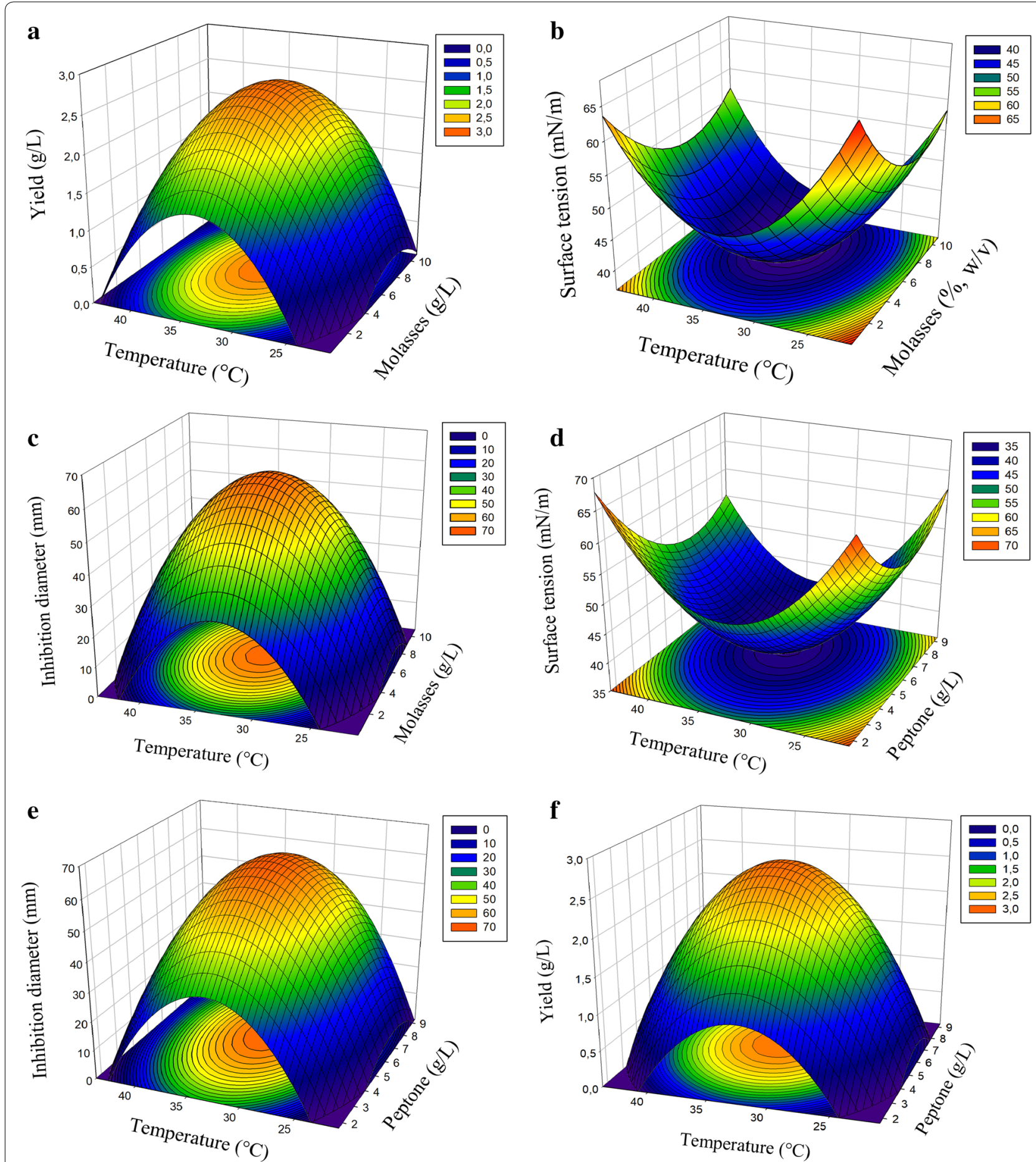

Fig. 1 3-D response surface plots showing the interactive effect of two factors on a selected response while keeping the third factor fixed at its central value. a Yield of biosurfactants as function of temperature and molasses concentration; $\mathbf{b}$ surface tension as function of temperature and molasses concentration; $\mathbf{c}$ inhibition diameter as function of temperature and molasses concentration; $\mathbf{d}$ surface tension as function of temperature and peptone concentration; $\mathbf{e}$ inhibition diameter as function of temperature and peptone concentration; $\mathbf{f}$ yield as function of temperature and peptone concentration

peptone concentration on production of biosurfactant by L. paracasei $\mathrm{N} 2$. The maximum yield and biosurfactant activities were observed at a peptone concentration of
$6 \mathrm{~g} / \mathrm{L}$ in the culture medium. The results of this study are in accordance with those reported by Rodrigues et al. (2006a). They found that the optimum medium 
composition for biosurfactant production from $S$. thermophilus A was at a peptone concentration of $5.0 \mathrm{~g} / \mathrm{L}$ and that, below this concentration, the yield of biosurfactant was low, as observed in the present study. However, in the present study, when the peptone concentration was more than $6 \mathrm{~g} / \mathrm{L}$ and temperature above $35^{\circ} \mathrm{C}$, a decrease in the yield and activities of biosurfactant was observed. The negative and significant $(p<0.05)$ effect of the quadratic term of peptone concentration on yield and antimicrobial activity of biosurfactant as well as its positive and significant $(p<0.05)$ effect on the reduction of surface tension confirm the decline in yield and activity of biosurfactant (Table 4). The inhibiting effect of high concentration of peptone may be explained by the retroinhibition effect of glutamine on glutamine synthetase, an enzyme involved in the metabolism of biosurfactants. Studies have indicated a direct relationship between increased glutamine synthetase activity and enhanced biosurfactant production in Pseudomonas aeruginosa grown in nitrate and proteose peptone media (Mulligan and Gibbs 1989). The nitrogen source is an important key to the regulation of biosurfactant production (Burkovski 2003). It represents a fundamental macronutrient for cellular metabolism. When the medium is nitrogen-limited, the protein synthesis is blocked and the cellular metabolism is switched to carbohydrate synthesis, and hence biosurfactant production is enhanced (Mulligan and Gibbs 1989). Conversely, an excess of nitrogen source, as observed in this study with increasing peptone concentration, leads to a decrease in the biosurfactant synthesis, driving the metabolism towards cell growth (Abalos et al. 2002).

As observed earlier, for temperature and peptone concentration or for temperature and molasses concentration, response surface plots of the interactive effect of molasses and peptone concentrations (data not shown) also showed that biosurfactant yield and activity increased with the increase in molasses and peptone concentrations up to the maximum yield and activity at a molasses concentration of $5.49-6.35 \%(\mathrm{w} / \mathrm{v})$ and peptone concentration of $5.5-6.5 \mathrm{~g} / \mathrm{L}$. This observation was confirmed by the linear coefficients of molasses concentration on the yield, antimicrobial activity and surface tension reduction of biosurfactant produced by $L$. paracasei N2 (Table 4). Molasses has been reported as a lowcost substrate for enhancing biosurfactant production by Bacillus spp. (Saimmai et al. 2011), Lactococcus lactis 53 and Streptococcus thermophilus A (Rodrigues et al. 2006b). The principal reason for the widespread use of molasses as a substrate is its low cost compared to other conventional sugar sources like sucrose or glucose, and also its high total sugar content, mainly sucrose, and its content of minerals, organic compounds and vitamins, which are valuable for the fermentation process as it is a by-product of the processing of sugar-rich crops (Saimmai et al. 2011). The response surface plots show that at high concentration of molasses, the yield and activities of the biosurfactant decrease. The coefficient of the quadratic term of molasses concentration shows its significant $(p<0.05)$ inhibiting effect on yield, antimicrobial activity and surface tension reduction of biosurfactant. The decrease in biosurfactant yield and activities may be due to the high concentration of salts in the molasses that may have raised osmotic pressure above acceptable levels, thus reducing the cell viability and suppressing the biosurfactant production (Doelle and Doelle 1990). Similar results were reported in the literature by Wei et al. (2005), who found that biosurfactant production initially increased with increasing molasses concentration until it reached a maximum value and then levelled off or decreased.

\section{Validation of the models}

The optimum conditions for each response evaluated are given in Table 5a. Based on the response surface plots of yield, the optimal concentrations of peptone and molasses and the optimal temperature were identified as $5.97 \mathrm{~g} / \mathrm{L}$, $6.28 \%(\mathrm{w} / \mathrm{v})$ and $34{ }^{\circ} \mathrm{C}$, respectively. The corresponding experiment performed under these conditions resulted in a biosurfactant concentration of $2.70 \mathrm{~g} / \mathrm{L}$, while the predicted value was $2.60 \mathrm{~g} / \mathrm{L}$. This confirms the closeness of the model to the experimental results. The optimal conditions for surface tension reduction were peptone concentration of $6.09 \mathrm{~g} / \mathrm{L}$, molasses concentration of $6.35 \%$ $(\mathrm{w} / \mathrm{v})$ and temperature of $33{ }^{\circ} \mathrm{C}$. The surface activity of biosurfactant produced was about $37.02 \pm 1.50 \mathrm{mN} / \mathrm{m}$, while the predicted value was $36.65 \mathrm{mN} / \mathrm{m}$. For the antimicrobial activity, the optimal conditions were peptone concentration of $6.51 \mathrm{~g} / \mathrm{L}$, molasses concentration of $5.49 \%(\mathrm{w} / \mathrm{v})$ and temperature of $33{ }^{\circ} \mathrm{C}$. The antimicrobial activity of biosurfactant produced expressed as inhibition diameter was about $63.89 \pm 2.10 \mathrm{~mm}$ while the predicted value was $62.07 \mathrm{~mm}$. These results also confirm the closeness of the model to the experimental results.

In order to determine optimal conditions for higher yield, antimicrobial activity and surface tension of biosurfactant produced by $L$. paracasei $\mathrm{N} 2$, a multi-response optimization methodology was carried out. In this analysis, molasses concentration was set at a constant level; peptone concentration and temperature were set within range. For surface activity, the response was set at minimum, since the desirable optimum is the combination of the independent variables that will give the maximum reduction in surface tension, while for yield and antimicrobial activity the responses were set as maximal. The desirability function was used in the multi-response 
Table 5 Predicted optimum conditions for each response assessed (A) and predicted and experimental values of the responses obtained at the optimum condition defined by multi-response optimization (B)

\begin{tabular}{|c|c|c|c|}
\hline \multirow[t]{2}{*}{ Factors } & \multicolumn{3}{|l|}{ Responses } \\
\hline & $\begin{array}{l}\text { Yield } \\
\text { (g/L) }\end{array}$ & $\begin{array}{l}\text { Inhibition diameter } \\
(\mathrm{mm})\end{array}$ & $\begin{array}{l}\text { Surface } \\
\text { tension } \\
(\mathrm{mN} / \mathrm{m})\end{array}$ \\
\hline \multicolumn{4}{|l|}{ A } \\
\hline Temperature $\left({ }^{\circ} \mathrm{C}\right)$ & 34 & 33 & 33 \\
\hline Peptone concentration (g/L) & 5.97 & 6.09 & 6.51 \\
\hline Molasses concentration $(\%, w / v)$ & 6.28 & 6.35 & 5.49 \\
\hline Responses & Predicted value & Experimental value & $p$-value (t-test) \\
\hline \multicolumn{4}{|l|}{ B } \\
\hline Yield $(g / L)$ & 2.60 & $2.70 \pm 0.10$ & 0.158 \\
\hline Inhibition diameter (mm) & 61.92 & $63.00 \pm 3.00$ & 0.567 \\
\hline Surface tension (mN/m) & 36.67 & $37.85 \pm 1.85$ & 0.331 \\
\hline
\end{tabular}

optimization process. It is defined as a transformation of variables to a scale of values ranging from 0 (i.e., at least one goal was unachievable) to 1 (i.e., all goals were easily met). As the response approaches the set criteria, the desirability value becomes closer to 1 . Solutions that matched the set criteria (high yield and antimicrobial activity, and low surface tension) were sought and listed using the statistical software STATGRAPHICS Centurion XVI. The optimum point with the maximum desirability function of 0.9 was selected. Hence, the predicted optimum condition for the maximum surface tension reduction of $36.67 \mathrm{mN} / \mathrm{m}$, yield of $2.60 \mathrm{~g} / \mathrm{L}$ and antimicrobial activity of $61.92 \mathrm{~mm}$ (expressed as inhibition diameter) was found to be at a molasses concentration of $5.95 \%(\mathrm{w} / \mathrm{v})$, a peptone concentration of $6.20 \mathrm{~g} / \mathrm{L}$ and a temperature of $33.13^{\circ} \mathrm{C}$.

The adequacy of the model equations for predicting the response values was tested by comparing the experimental and predicted values at optimum conditions. It can be seen from Table $5 \mathrm{~b}$ that there is no significant difference $(p<0.05)$ between the experimental and the predicted values.

\section{Partial characterization of biosurfactant}

Elemental analysis revealed that the biosurfactant produced by $L$. paracasei $\mathrm{N} 2$ contained $44.347 \pm 0.007 \%$ of carbon, $6.590 \pm 0.014 \%$ of hydrogen, $7.150 \pm 0.014 \%$ of nitrogen, $0.805 \pm 0.006 \%$ of sulphur and $40.810 \pm 0.028 \%$ of oxygen. Results of the chemical analysis show that the biosurfactant produced was mainly composed of proteins $(63.64 \pm 0.24 \mathrm{~g} / 100 \mathrm{gDM})$ and sugars $(35.26 \pm 1.10 \mathrm{~g} / 100 \mathrm{gDM})$. This result is in accordance with the elemental analysis, in which a high proportion of nitrogen and oxygen were observed. A lesser amount of lipid was found $(1.10 \pm 0.70 \mathrm{~g} / 100 \mathrm{gDM})$ and hence the biosurfactant produced could be a glycolipoprotein. Vecino et al. (2015) also reported the production of a glycolipoprotein biosurfactant by L. pentosus.

In order to confirm the glycolipoprotein nature of the biosurfactant observed in this study, FTIR analysis was carried out (Fig. 2). The peaks observed at $2962 \mathrm{~cm}^{-1}$ assigned to the symmetric stretch $(\mathrm{C}-\mathrm{H})$ of $-\mathrm{CH}_{2}$ and $-\mathrm{CH}_{3}$ groups of aliphatic chains, and the peaks at $1402 \mathrm{~cm}^{-1}$ assigned to $\mathrm{CH}_{2}-\mathrm{CH}_{3}$ stretching vibrations indicated the presence of aliphatic chains in the structure of the biosurfactant. This observation is in line with the previous results reported by Dehghan-Noude et al. (2005). Peaks corresponding to $\mathrm{O}-\mathrm{H}$ and $\mathrm{N}-\mathrm{H}$ stretching were observed at 3206 and $3053 \mathrm{~cm}^{-1}$, respectively, which is similar to the report of Gudiña et al. (2015). The

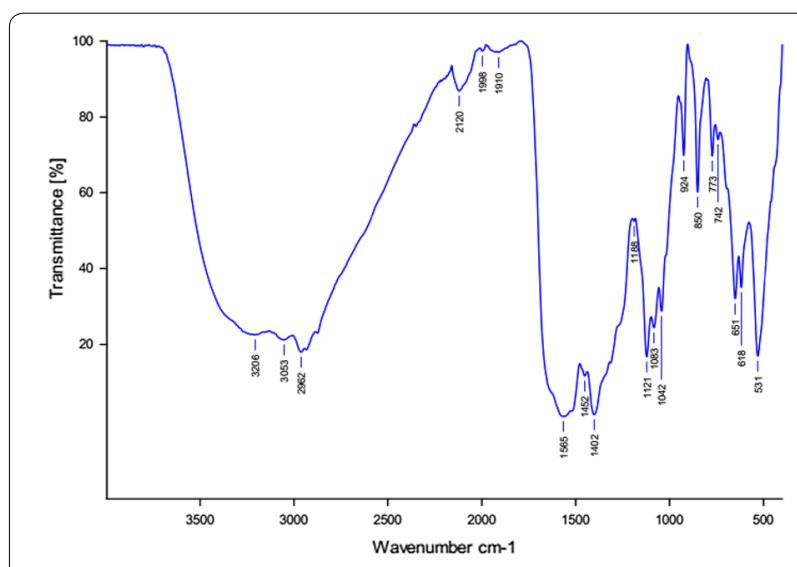

Fig. 2 FTIR spectrum of biosurfactants produced by the strain $L$. paracasei subsp. tolerans N2 with molasses as carbon source 
peak observed at $1565 \mathrm{~cm}^{-1}$ resulting from the deformation mode of the $\mathrm{N}-\mathrm{H}$ bond combined with $\mathrm{C}-\mathrm{N}$ stretching mode (amide II band) could be indicative of the presence of peptide components. Similar peaks were reported in the literature for lactobacilli-derived biosurfactant (Sharma et al. 2015). These peaks confirm the presence of proteins in the composition of the biosurfactants. The presence of sugars in the composition of the biosurfactants was confirmed by the peaks observed at 1121 and $1083 \mathrm{~cm}^{-1}$ corresponding to $\mathrm{C}-\mathrm{O}$ stretching bands formed between carbon atoms and hydroxyl groups. The peak corresponding to $\mathrm{C}-\mathrm{O}$ stretching of sugars was also observed with biosurfactant produced by L. agilis CCUG31450 (Gudiña et al. 2015). Moreover, the peak at $1042 \mathrm{~cm}^{-1}$ corresponding to the PII polysaccharide band that is characteristic of bond vibrations in the $\mathrm{C}-\mathrm{O}-\mathrm{C}$ group indicates the presence of polysaccharides in the biosurfactant produced by $L$. paracasei $\mathrm{N} 2$. Similar results were reported by Sharma and Singh Saharan (2014). Peaks at 742 and $773 \mathrm{~cm}^{-1}$ correspond to the bending vibration of a $-\mathrm{CH}_{2}$ group. Thus, based on these results it can be concluded that the biosurfactant produced by the strain L. paracasei $\mathrm{N} 2$ using molasses as a carbon source is a glycolipoprotein in nature.

\section{Antimicrobial activity of biosurfactant}

The antimicrobial activity of biosurfactant produced by $L$. paracasei $\mathrm{N} 2$ using molasses as substrate was quantified through the determination of its MIC and MBC against several pathogenic or spoilage microorganisms. Regarding MIC, all the tested pathogens were sensitive to biosurfactant, with MIC values ranging from 3.2 to $12.8 \mathrm{mg} /$ $\mathrm{mL}$ (Table 6). Gram-positive bacteria S. aureus STP1 and Bacillus sp. $\mathrm{BC} 1$ were more sensitive to biosurfactants $(\mathrm{MIC}=3.2 \mathrm{mg} / \mathrm{mL})$. The MIC values observed in this study were compared to those reported in the literature with other lactobacilli biosurfactants, and the details are given in Table 7 . The nature and chemical composition of biosurfactants depend on the biosurfactant-producing

\begin{tabular}{|c|c|c|}
\hline Microbial strains & $\mathrm{MIC}(\mathrm{mg} / \mathrm{mL})$ & $\mathrm{MBC}(\mathrm{mg} / \mathrm{mL})$ \\
\hline Pseudomonas aeruginosa PSB2 & 6.40 & 25.6 \\
\hline Pseudomonas putida PSJ1 & 6.40 & 12.8 \\
\hline Salmonella sp. SL2 & 12.80 & 25.6 \\
\hline E. coli MTCC 118 & 12.80 & 50.0 \\
\hline Bacillus sp. BC1 & 3.20 & 12.8 \\
\hline Staphylococcus aureus STP1 & 3.20 & 6.40 \\
\hline
\end{tabular}

strain and the substrate used for production, which could explain the variability in MIC among different lactobacilli strains.

The $\mathrm{MBC}$ required to kill $99.99 \%$ of bacterial strains was found to be between 6.4 and $50 \mathrm{mg} / \mathrm{mL}$ (Table 6). This bactericidal activity of biosurfactants is due to their ability to alter elements of cellular structures such as cell wall and membrane (Inès and Dhouha 2015). In order to check this, the SEM analysis was performed using $E$. coli MTCC 118. The untreated cells presented a very smooth cell surface, with intact normal morphology (Fig. 3). Cells treated with biosurfactants showed damage on their surface and had lost their cell shape integrity. They appeared distorted and collapsed due to disruption in the bacterial cell wall, which represents the cross-linked structure that gives cells shape, strength and osmotic stability. (Zengin and Baysal 2014). This result suggested that bacterial cell walls and outer membranes are the most likely targets of biosurfactants. Sambanthamoorthy et al. (2014) also reported that cell membranes of $A$. baumannii and $S$. aureus were the target of biosurfactants produced by $L$. jensenii and L. rhamnosus.

The potential of the biosurfactant produced in this study by $L$. paracasei using molasses as substrate was compared with previous reports on lactobacilli biosurfactants. Based on data in Table 7, it can be concluded that with the conventional synthetic media (MRS broth), the yield of biosurfactants was low. The yield of biosurfactants was high when a low-cost substrate like molasses was used. The chemical nature of biosurfactants observed in the present study is in accordance with cited reports and the antimicrobial activity of biosurfactants varies with the producing strain and the substrate used. Although biosurfactants from different lactobacilli seem to have similar chemical natures after FTIR analysis, their MIC values were found to be different.

\section{Conclusions}

In the present study, the application of Plackett-Burman design revealed that temperature and peptone and sugar cane molasses concentrations were the main significant factors affecting biosurfactant production by $L$. paracasei subsp. tolerans $\mathrm{N} 2$. The optimization of biosurfactant production using a central composite design through response surface methodology led to an improvement in the production yield $(2.70 \mathrm{~g} / \mathrm{L})$ to a value four times higher than that before optimization $(0.75 \mathrm{~g} / \mathrm{L})$. To the best of our knowledge, this is the first report on biosurfactant produced by $L$. paracasei species with the highest yield. Partial characterization of the biosurfactants revealed that they are glycolipoprotein in nature. The biosurfactant exhibited bactericidal activity against several Gram-positive and Gram-negative pathogens, with 
Table 7 Comparison of the properties of biosurfactants from this study with those reported in the literature

\begin{tabular}{|c|c|c|c|c|c|c|}
\hline \multirow{2}{*}{$\begin{array}{l}\text { Biosurfactant- } \\
\text { producing strains }\end{array}$} & \multirow[t]{2}{*}{ Substrates } & \multirow[t]{2}{*}{ Yield (g/L) } & \multirow[t]{2}{*}{ Nature } & \multicolumn{2}{|l|}{$\mathrm{MIC}(\mathrm{mg} / \mathrm{mL})$} & \multirow[t]{2}{*}{ References } \\
\hline & & & & Pathogens & Values & \\
\hline \multirow[t]{2}{*}{ L.jensenii P6A } & MRS broth & 0.27 & Glycolipoprotein & Escherichia coli & 0.016 & Morais et al. (2017) \\
\hline & & & & S. saprophyticus & 0.128 & \\
\hline \multirow[t]{2}{*}{ L. gasseri P65 } & MRS broth & 0.42 & Glycolipoprotein & Escherichia coli & 0.016 & \\
\hline & & & & S. saprophyticus & 0.128 & \\
\hline \multirow[t]{2}{*}{ Lactococcus lactis 53} & MRS broth & 0.10 & Glycoprotein & S. epidermidis GB 9/6 & $>40$ & Rodrigues et al. (2006a) \\
\hline & & & & S. aureus GB 2/1 & $>40$ & \\
\hline \multirow[t]{3}{*}{ L.jensenii 25258} & MRS broth & - & - & E. coli & 50 & Sambanthamoorthy et al. (2014) \\
\hline & MRS broth & - & - & S. aureus UMS-1 & 50 & \\
\hline & MRS broth & - & - & ${ }^{*}$ MR S. aureus & 50 & \\
\hline \multirow[t]{3}{*}{ L.rhamnosus } & MRS broth & - & - & E. coli, & $>50$ & \\
\hline & & - & - & S. aureus UMS-1 & $>50$ & \\
\hline & & - & - & MRS. aureus & $>50$ & \\
\hline \multirow[t]{3}{*}{ L. agilis CCUG31450 } & Cheese whey & 0.96 & Glycoprotein & S. aureus & $>5$ & Gudiña et al. (2015) \\
\hline & & & & P. aeruginosa & $>5$ & \\
\hline & MRS broth & 0.084 & Glycoprotein & - & - & \\
\hline \multirow[t]{3}{*}{ L.paracasei } & MRS broth & & - & S. aureus & 50 & \\
\hline & & & - & E. coli & 25 & \\
\hline & & & - & P. aeruginosa & $>50$ & \\
\hline \multirow[t]{6}{*}{ L. paracasei N2 } & Molasses & 2.70 & Glycolipoprotein & P. aeruginosa PSB2 & 6.4 & This study \\
\hline & & & & Salmonella sp. SL2 & 6.4 & \\
\hline & & & & E. coli MTCC 118 & 12.8 & \\
\hline & & & & P. putida PSJ1 & 12.8 & \\
\hline & & & & Bacillus sp. BC1 & 3.2 & \\
\hline & & & & S. aureus STP1 & 3.2 & \\
\hline
\end{tabular}
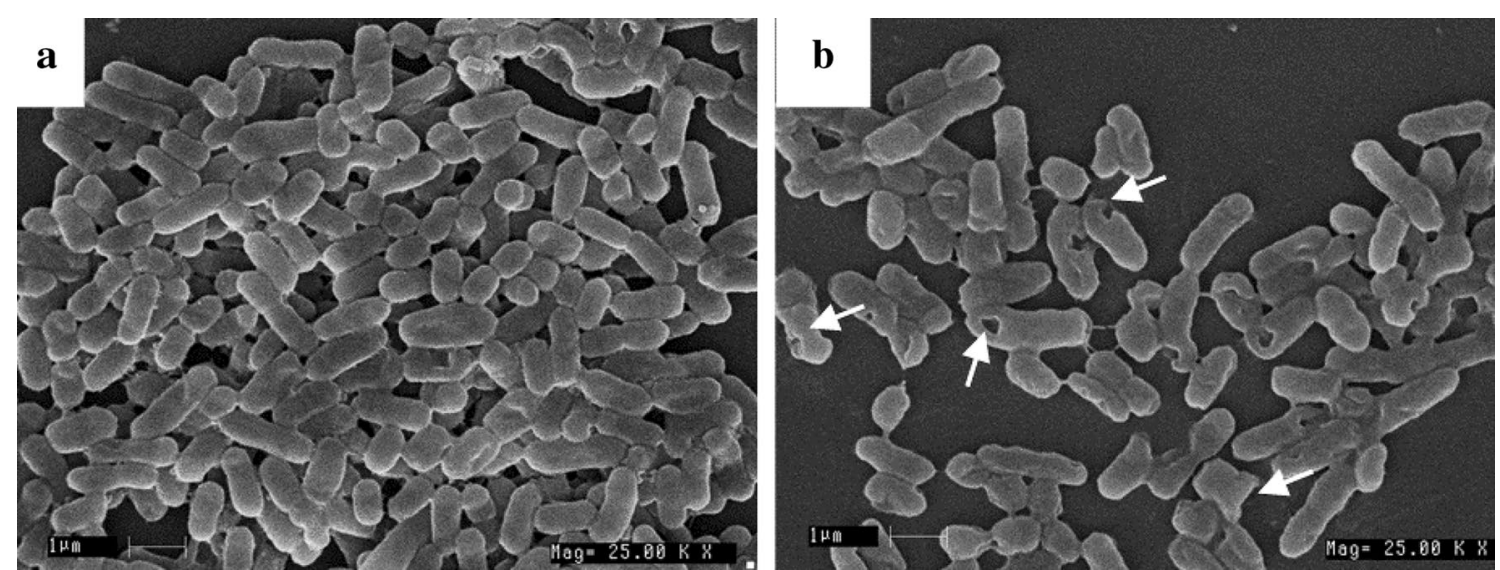

Fig. 3 SEM images of untreated E. coli MTCC-118 (a) and E. coli MTCC-118 treated with biosurfactants (b)

bacterial cell walls and membranes as the most likely target. The results of this study suggested sugar cane molasses as a low-cost substrate which can be used to enhance large-scale production of biosurfactant by $L$. paracase $i$ $\mathrm{N} 2$, and the optimization procedure adopted in this study was found to improve the biosurfactant production. As 
these microorganisms are considered to be Generally Recognized As Safe (GRAS), there is a great potential for the scale-up of processes and application of these antimicrobial compounds in the medical field as well as in the food industry.

\section{Abbreviations}

DNA: deoxyribonucleic acid; RNA: ribonucleic acid; BLAST: basic local alignment search tool; MUSCLE: multiple sequence comparison by log-expectation; TSB: trypticase soy broth; MEGA: molecular evolutionary genetics analysis.

\section{Authors' contributions}

All authors directly participated in the planning, execution, or analysis of this study. All authors read and approved the final manuscript.

\section{Author details \\ ${ }^{1}$ Department of Food Sciences and Nutrition, National School of Agro-Indus- trial Sciences, University of Ngaoundéré, P.O Box 455, Ngaoundéré, Cameroon. ${ }^{2}$ Centre for Food and Nutrition Research Institute of Medical Research and Medicinal Plants Studies, P.O Box. 6163, Yaoundé, Cameroon. ${ }^{3}$ Depart- ment of Microbiology and Fermentation Technology, CSIR-Central Food Technological Research Institute, Mysore, Karnataka 570020, India.}

\section{Acknowledgements}

The authors would like to thank the Director of the National School of AgroIndustrial Sciences, University of Ngaoundéré (Cameroon) and the Director of CSIR-Central Food Technological Research Institute, Mysore (India) for permission to carry out this work in their institutes.

\section{Competing interest}

The authors declare that they have no competing interests.

\section{Availability of data and materials}

The data sets supporting the conclusions of this article are included in the article.

\section{Consent for publication}

All authors read the final manuscript and approved its submission to Bioresources and Bioprocessing.

\section{Ethics approval and consent to participate}

Not applicable.

\section{Funding}

Funding for this research work was granted by the TWAS-CSIR Postgraduate Fellowship.

\section{Publisher's Note}

Springer Nature remains neutral with regard to jurisdictional claims in published maps and institutional affiliations.

Received: 7 August 2018 Accepted: 28 November 2018

Published online: 21 December 2018

\section{References}

AACC (1999) Kjeldahl method AACC 46-12.01. 10-12. https://doi.org/10.1094/ aaccintmethod-46-12.01

Abalos A, Maximo F, Manresa MA, Bastida J (2002) Utilization of response surface methodology to optimize the culture media for the production of rhamnolipids by Pseudomonas aeruginosa AT10. J Chem Technol Biotechnol 77:777-784. https://doi.org/10.1002/jctb.637

Banat IM, Makkar RS, Cameotra SS (2000) Potential commercial applications of microbial surfactants. Appl Microbiol Biotechnol 53:495-508. https://doi. org/10.1007/s002530051648
Bas D, Boyaci IH (2007) Modeling and optimization i: usability of response surface methodology. J Food Eng 78:836-845. https://doi.org/10.1016/j. jfoodeng.2005.11.024

Burkovski A (2003) Ammonium assimilation and nitrogen control in Corynebacterium glutamicum and its relatives: an example for new regulatory mechanisms in actinomycetes. FEMS Microbiol Rev 27:617-628. https://doi.org/10.1016/S0168-6445(03)00067-6

Dehghan-Noude G, Housaindokht M, Bazzaz BSF (2005) Isolation, characterization, and investigation of surface and hemolytic activities of a lipopeptide biosurfactant produced by Bacillus subtilis ATCC 6633. J Microbiol 43:272-276

Dellaglio F, Dicks L (1991) Designation of ATCC 334 in place of ATCC 393 (NCDO 161) as the neotype strain of Lactobacillus casei subsp. casei and rejection of the name Lactobacillus paracasei (Collins et al., 1989). Int J Syst Bacteriol 41:340-342. https://doi.org/10.1099/00207713-41-2-340

Desai JD, Banat IM (1997) Microbial production of surfactants and their commercial potential. Microbiol Mol Biol Rev 61:47-64. https://doi. org/10.1016/S0140-6701(97)84559-6

Devesa-Rey R, Vecino X, Barral MT, Cruz JM, Moldes AB (2011) Study of the sorption of biosurfactants from Lactobacillus Pentosus on sediments. Int Sch Sci Res Innov 5:403-407

Doelle MB, Doelle HW (1990) Sugar-cane molasses fermentation by Zymomonas mobilis. Appl Microbiol Biotechnol 33:31-35. https://doi. org/10.1007/BF00170565

Dubois M, Gilles K, Hamilton J et al (1956) Colorimetric method for determination of sugars and related substances. Anal Chem 28:350-356. https://doi. org/10.1021/ac60111a017

Fracchia L, Cavallo M, Allegrone G, Martinotti MG (2010) A Lactobacillusderived biosurfactant inhibits biofilm formation of human pathogenic Candida albicans biofilm producers. In: Méndez-Vilas A (ed) Current research, technology and education topics in applied microbiology and microbial biotechnology. Microbiology Book Series, vol 2, no 2. FORMATEX, Spain, pp 827-837

Freitas de Oliveira DW, Lima França ÍW, Nogueira Félix AK et al (2013) Kinetic study of biosurfactant production by Bacillus subtilis LAMI005 grown in clarified cashew apple juice. Colloids Surfaces B Biointerfaces 101:34-43. https://doi.org/10.1016/j.colsurfb.2012.06.011

Ghribi D, Ellouze-Chaabouni S (2011) Enhancement of Bacillus subtilis lipopeptide biosurfactants production through optimization of medium composition and adequate control of aeration. Biotechnol Res Int 2011:1-6. https://doi.org/10.4061/2011/653654

Griffin HL, Greene RV, Cotta MA (1992) Isolation and characterization of an alkaline protease from the marine shipworm bacterium. Curr Microbiol 24:111-117

Gudiña EJ, Rocha V, Teixeira JA, Rodrigues LR (2010) Antimicrobial and antiadhesive properties of a biosurfactant isolated from Lactobacillus paracasei ssp. paracasei A20. Lett Appl Microbiol 50:419-424. https://doi. org/10.1111/j.1472-765X.2010.02818.X

Gudiña EJ, Teixeira JA, Rodrigues LR (2011) Biosurfactant-producing Lactobacilli: screening, production profiles, and effect of medium composition. Appl Environ Soil Sci 2011:1-9. https://doi.org/10.1155/2011/201254

Gudiña EJ, Fernandes EC, Teixeira JA, Rodrigues LR (2015) Antimicrobial and anti-adhesive activities of cell-bound biosurfactant from Lactobacillus agilis CCUG31450. RSC Adv 5:90960-90968. https://doi.org/10.1039/ C5RA11659G

Guo XH, Kim JM, Nam HM et al (2010) Screening lactic acid bacteria from swine origins for multistrain probiotics based on in vitro functional properties. Anaerobe 16:321-326. https://doi.org/10.1016/j.anaer obe.2010.03.006

Hamzehlou P, Sepahy AA, Mehrabian S, Hosseini F (2018) Production of vitamins B3, B6 and B9 by Lactobacillus isolated from traditional yogurt samples from 3 cities in Iran, winter 2016. Appl Food Biotechnol 5(2):107-120

Huang X, Peng K, Feng Y et al (2013) Separation and characterization of effective demulsifying substances from surface of Alcaligenes sp. S-XJ-1 and its application in water-in-kerosene emulsion. Bioresour Technol 139:257264. https://doi.org/10.1016/j.biortech.2013.04.043

Inès M, Dhouha G (2015) Lipopeptide surfactants: production, recovery and pore forming capacity. Peptides 71:100-112. https://doi.org/10.1016/j. peptides.2015.07.006

Kammoun R, Naili B, Bejar S (2008) Application of a statistical design to the optimization of parameters and culture medium for a-amylase 
production by Aspergillus oryzae CBS 819.72 grown on gruel (wheat grinding by-product). Bioresour Technol 99:5602-5609. https://doi. org/10.1016/j.biortech.2007.10.045

Kumar S, Stecher G, Tamura K (2016) MEGA7 : molecular evolutionary genetics analysis version 7. 0 for bigger datasets. MBE Adv Access 1-11. https:// doi.org/10.1093/molbev/msw054

Li C, Bai J, Cai Z, Ouyang F (2002) Optimization of a cultural medium for bacteriocin production by Lactococcus lactis using response surface methodology. J Biotechnol 93:27-34

Lobna AM, Ahmed ZAA (2013) Identification and characterization of biosurfactants produced by Rodococcus equi and Bacillus methylotrophicus. J Biol chem Environ Sci 8:341-358

Makkar R, Cameotra S (2002) An update on the use of unconventional substrates for biosurfactant production and their new applications. Appl Microbiol Biotechnol 58:428-434. https://doi.org/10.1007/s0025 3-001-0924-1

Makkar RS, Cameotra SS, Banat IM (2011) Advances in utilization of renewable substrates for biosurfactant production. AMB Express 1:5. https://doi. org/10.1186/2191-0855-1-5

Mbawala A, Mouafo HT, Kom RR (2013) Antibacterial activity of Lactobacillus biosurfactants against Pseudomonas spp. isolated from fresh beef. Nov Int J Biotechnol Biosci 2:7-22

Morais IMC, Cordeiro AL, Teixeira GS et al (2017) Biological and physicochemical properties of biosurfactants produced by Lactobacillus jensenii-P 6A and Lactobacillus gasseri-P 65. Microb Cell Fact. https://doi.org/10.1186/ s12934-017-0769-7

Mouafo TH, Mbawala A, Ndjouenkeu R (2018) Effect of different carbon sources on biosurfactants' production by three strains of Lactobacillus spp. Biomed Res Int 2018:15. https://doi.org/10.1155/2018/5034783

Moussa TAA, Mohamed MS, Samak N (2014) Production and characterization of di-rhamnolipid produced by Pseudomonas aeruginosa TMN. Brazilian J Chem Eng 31:867-880. https://doi.org/10.1590/0104-6632.20140314s0 0002473

Mulligan CN, Gibbs BF (1989) Correlation of nitrogen-metabolism with biosurfactant production by Pseudomonas-aeruginosa. Appl Environ Microbiol 55:3016-3019

Najafi AR, Rahimpour MR, Jahanmiri AH et al (2011) Interactive optimization of biosurfactant production by Paenibacillus alvei ARN63 isolated from an Iranian oil well. Colloids Surf B Biointerfaces 82:33-39. https://doi. org/10.1016/j.colsurfb.2010.08.010

Rodrigues L, Teixeira J, Oliveira R, Van Der Mei HC (2006a) Response surface optimization of the medium components for the production of biosurfactants by probiotic bacteria. Process Biochem 41:1-10. https://doi. org/10.1016/.procbio.2005.01.030

Rodrigues LR, Teixeira JA, Oliveira R (2006b) Low-cost fermentative medium for biosurfactant production by probiotic bacteria. Biochem Eng J 32:135-142. https://doi.org/10.1016/j.bej.2006.09.012

Saimmai A, Sobhon V, Maneerat S (2011) Molasses as a whole medium for biosurfactants production by bacillus strains and their application. Appl Biochem Biotechnol 165:315-335. https://doi.org/10.1007/s1201 $0-011-9253-8$

Saitou N, Nei M (1987) The neighbour-joining method: a new method for reconstructing phylogenetic trees. Mol Biol Evol 4:406-425

Salar RK, Purewal SS, Bhatti MS (2016) Optimization of extraction conditions and enhancement of phenolic content and antioxidant activity of pearl millet fermented with Aspergillus awamori MTCC-548. Resour Technol 2:148-157. https://doi.org/10.1016/j.reffit.2016.08.002

Sambanthamoorthy K, Feng X, Patel R et al (2014) Antimicrobial and antibiofilm potential of biosurfactants isolated from lactobacilli against multi-drug-resistant pathogens. BMC Microbiol 14:197. https://doi. org/10.1186/1471-2180-14-197

Satpute SK, Kulkarni GR, Banpurkar AG, Banat IM (2016) Review biosurfactant/s from Lactobacilli species: properties, challenges and potential biomedical applications. J Basic Microbiol 56:1-19. https://doi.org/10.1002/ jobm.201600143

Sayyad SA, Panda BP, Javed S, Ali M (2007) Screening of nutrient parameters for lovastatin production by Monascus purpureus MTCC 369 under submerged fermentation using Plackett-Burman design. Res J Microbiol 2:601-605. https://doi.org/10.1007/s00253-006-0577-1

Sharma D, Singh Saharan B (2014) Simultaneous production of biosurfactants and bacteriocins by probiotic Lactobacillus casei MRTL3. Int J Microbiol. https://doi.org/10.1155/2014/698713

Sharma D, Ansari MJ, Gupta S et al (2015) Structural characterization and antimicrobial activity of a biosurfactant obtained from Bacillus pumilus DSVP18 grown on potato peels. Jundishapur J Microbiol. https://doi. org/10.5812/jjm.21257

Song TS, Kim JY, Kim KH et al (2010) In vitro evaluation of probiotic lactic acid bacteria isolated from dairy and non-dairy environments. Food Sci Biotechnol 19:19-25. https://doi.org/10.1007/s10068-010-0003-4

Telmo C, Lousada J, Moreira N (2010) Proximate analysis, backwards stepwise regression between gross calorific value, ultimate and chemical analysis of wood. Bioresour Technol 101:3808-3815. https://doi.org/10.1016/j. biortech.2010.01.021

Topisirovic L, Kojic M, Fira D et al (2006) Potential of lactic acid bacteria isolated from specific natural niches in food production and preservation. Int J Food Microbiol 112:230-235. https://doi.org/10.1016/.ijfoodmicr 0.2006 .04 .009

Vecino X, Barbosa-Pereira L, Devesa-Rey R et al (2015) Optimization of extraction conditions and fatty acid characterization of Lactobacillus pentosus cell-bound biosurfactant/bioemulsifier. J Sci Food Agric 95:313-320. https://doi.org/10.1002/jsfa.6720

Wei YH, Chou CL, Chang JS (2005) Rhamnolipid production by indigenous Pseudomonas aeruginosa $\mathrm{J} 4$ originating from petrochemical wastewater. Biochem Eng J 27:146-154. https://doi.org/10.1016/j.bej.2005.08.028

Xu Q, Nakajima M, Liu Z, Shiina T (2011) Biosurfactants for microbubble preparation and application. Int J Mol Sci 12:462-475. https://doi.org/10.3390/ ijms12010462

Zengin H, Baysal AH (2014) Antibacterial and antioxidant activity of essential oil terpenes against pathogenic and spoilage-forming bacteria and cell structure-activity relationships evaluated by SEM microscopy. Molecules 19:17773-17798. https://doi.org/10.3390/molecules191117773

\section{Submit your manuscript to a SpringerOpen ${ }^{\circ}$ journal and benefit from:}

- Convenient online submission

- Rigorous peer review

- Open access: articles freely available online

- High visibility within the field

- Retaining the copyright to your article

Submit your next manuscript at $\boldsymbol{\nabla}$ springeropen.com 